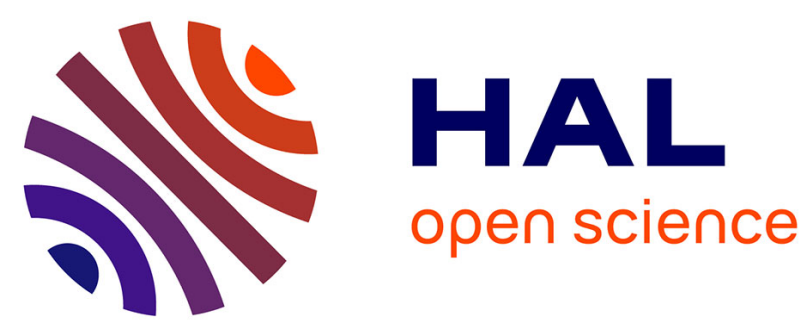

\title{
Soil fauna abundance and diversity in a secondary semi-evergreen forest in Guadeloupe (Lesser Antilles): influence of soil type and dominant tree species
}

Gladys Loranger-Merciris, Daniel Imbert, France Bernhard-Reversat, Jean-François Ponge, Patrick Lavelle

\section{To cite this version:}

Gladys Loranger-Merciris, Daniel Imbert, France Bernhard-Reversat, Jean-François Ponge, Patrick Lavelle. Soil fauna abundance and diversity in a secondary semi-evergreen forest in Guadeloupe (Lesser Antilles): influence of soil type and dominant tree species. Biology and Fertility of Soils, 2007, 44 (2), pp.269-276. 10.1007/s00374-007-0199-5 . hal-00495371

\section{HAL Id: hal-00495371 https://hal.science/hal-00495371}

Submitted on 10 Aug 2010

HAL is a multi-disciplinary open access archive for the deposit and dissemination of scientific research documents, whether they are published or not. The documents may come from teaching and research institutions in France or abroad, or from public or private research centers.
L'archive ouverte pluridisciplinaire HAL, est destinée au dépôt et à la diffusion de documents scientifiques de niveau recherche, publiés ou non, émanant des établissements d'enseignement et de recherche français ou étrangers, des laboratoires publics ou privés. 


\title{
Soil fauna abundance and diversity in a secondary semi-evergreen forest in Guadeloupe (Lesser Antilles): influence of soil type and dominant tree species
}

Gladys Loranger-Merciris · Daniel Imbert · France Bernhard-Reversat · Jean-François Ponge · Patrick Lavelle

\author{
G. Loranger-Merciris · F. Bernhard-Reversat · P. Lavelle
}

UMR 137 BIOSOL, Université Pierre et Marie Curie-Paris 6/IRD, Laboratoire d'Ecologie des Sols Tropicaux, 32 Avenue Henri Varagnat, 93143 Bondy Cedex, France

G. Loranger-Merciris (corresponding author) $\cdot$ D. Imbert

Université des Antilles et de la Guyane, Faculté des Sciences Exactes et Naturelles, DYNECAR EA 926, Laboratoire de Biologie et de Physiologie Végétales, BP 592, 97159 Pointe à Pitre Cedex, Guadeloupe, France, e-mail: glorange@univ-ag.fr

\section{J.-F. Ponge}

Muséum National d'Histoire Naturelle, CNRS UMR 5176, 4 Avenue du Petit Château, 91800 Brunoy, France

\begin{abstract}
The importance of secondary tropical forests regarding the maintenance of soil fauna abundance and diversity is poorly known. The aims of this study were (1) to describe soil fauna abundance and diversity and (2) to assess the determinants of soil fauna abundance and diversity in two stands of a tropical semi-evergreen secondary forest. Soil macrofauna and microarthropod abundance and soil macrofauna diversity were described at two sites developed on different soils and with different site histories: (1) a natural secondary stand (natural forest) under two dominant tree species, Pisonia subcordata and Bursera simaruba, and (2) a planted secondary forest (planted forest) under three tree species, B. simaruba, Swietenia macrophylla, and Tabebuia heterophylla. The effects of both soil and main tree species' litter quality were assessed to explain soil fauna abundance and
\end{abstract}


diversity. The abundance of soil macrofauna was significantly higher in the soil under the planted forest, and soil fauna communities were contrasted between the two sites. In the planted forest, a soil-dwelling macrofauna community developed (mainly consisting of the anecic earthworm Polypheretima elongata). In the natural forest, soil macrofauna and microarthropod communities were located at the soil surface. The effect of plant litter quality varied according to each dominant tree species and was superimposed to soil effect. The lowest macrofauna abundance was associated with B. simaruba in the natural forest. T. heterophylla supported a much greater macrofauna community than the two other tree species studied at the same soil, and it appears likely that this is due to the palatability of its leaves compared with the other trees (low lignin, tannins, soluble phenols).

Keywords Biodiversity $\cdot$ Litter quality $\cdot$ Macrofauna $\cdot$ Microarthropods $\cdot$ Semi-evergreen forests

\section{Introduction}

Secondary forests provide goods and ecosystems services to local populations. Brown and Lugo (1990) pointed out that an increasing proportion (40\%) of tropical woodlands were secondary forests, i.e., forests that have been, or are still, influenced by human activities. These authors emphasized the need for a sound, sustainable management of such forested areas, in terms of both biodiversity conservation and human welfare. As in primary forests, soil fauna is essential in secondary forests to efficient nutrient cycling, organic matter dynamics, and maintenance of soil physical structure. Such processes are key determinants for primary production and ecosystem C storage (Petersen and Luxton 1982; Lavelle 1997).

Tropical semi-evergreen dry forests can be regarded as one of the most endangered major tropical ecosystem (Janzen 1988; Lerdau et al. 1991; Gillespie 1999). During the last four centuries, they have been extensively converted to pastures or farmlands, and the remaining secondary woodlands have been exploited for timber, fuel wood, or charcoal production (Murphy and Lugo 1986; Lerdau et al. 1991). In the Caribbean islands, forest decline in dry areas proceeded at an especially high rate due to the small size of landmasses and to the high density of populations (Lugo et al. 1981). At the present time, patches of semi-evergreen, dry secondary natural forests remain on the steepest slopes of these islands. Secondary woodlands issued from forest plantations and intended for timber production may be found on more suitable locations. Soil fauna diversity and its linkage with the whole ecosystem structure and functioning is still poorly known in such forests, as for the 
other types of tropical secondary forests (Bernhard-Reversat et al. 2001; Höfer et al. 2001; Warren and Zou 2002).

Soil macrofauna and microarthropod abundance and soil macrofauna diversity were described in two stands of a secondary semi-evergreen dry forest in the island of Grande-Terre, Guadeloupe (Lesser Antilles). These stands had both different soil types and site histories and exhibited various main canopy tree species. The aims of the present work were (1) to measure soil fauna abundance and diversity at the two contrasting sites and (2) to assess the influence of soil physicochemical characteristics and of main tree species on soil fauna abundance and diversity.

\section{Materials and methods}

Study sites

The study was carried out in the northern part of the island of Grande-Terre (Guadeloupe, French West Indies) in a tropical semi-evergreen lowland forest (UNESCO classification, Anonymous) that extended more than 2,700 ha. The landscape was characterized by a series of plateaus with frequent outcroppings of the Pleistocene limestone bedrock. The annual rainfall averaged 1,300 mm, February and March being the driest months with less than $60 \mathrm{~mm}$ per month on average. The mean annual temperature at the study area was $26^{\circ} \mathrm{C}$.

One study site, the natural forest, was located in an old growth, secondary semi-evergreen forest that stretched over a $35-\mathrm{km}$ fault scarp where the steep slope reached $45 \%$. The soil was a shallow calcareous Leptosol (FAO-UNESCO classification, Driessen et al. 2001). Forty-three plant species were present, but Pisonia subcordata L. and Bursera simaruba (L.) Sarg., two native deciduous tree species, accounted for $40 \%$ of the total basal canopy area (Imbert and Portecop 1992).

The other site, the planted forest, was located in a 50-year-old forest plantation grown on a calcareous Vertisol that developed at the edge of a plateau. Despite subsequent silvicultural treatments, natural regeneration of native species has occurred. When the study was conducted, a thick understorey was present, and 46 plant species were present. Among the most abundant tree species were Swietenia macrophylla King (planted, exotic), Tabebuia heterophylla (DC.) Britton (planted, native), and B. simaruba (spontaneous, native), which covered 32, 30 , and $7 \%$ of the total canopy area, respectively (unpublished data). 
Soil physicochemical characteristics

In the natural forest, the upper horizon (A horizon) was $10 \mathrm{~cm}$ thick, and the lower horizon (A/C horizon) was found between 10 and $40 \mathrm{~cm}$ deep. In the planted forest, the A horizon was $20 \mathrm{~cm}$ thick, and the lower horizon (SV horizon) was found between 20 and $60 \mathrm{~cm}$ deep. Soil texture was determined at each site, for upper and lower horizons

Ten soil cores of $40 \mathrm{~cm}$ deep were taken randomly at each site, at the beginning of the experiment. These cores were separated in several layers, 0-10, 10-20, 20-30, and 30-40 cm. Samples were sieved to $2 \mathrm{~mm}$ and homogenized. Total $\mathrm{C}$ and $\mathrm{N}$ were performed on subsamples sieved at $200 \mu \mathrm{m}$ and determined with a CHN Carbo Erba ${ }^{\circledR}$ auto-analyzer.

At each site, three soil samples (10 cm deep) were taken randomly bimonthly during 1 year, and percent moisture was calculated (drying during $72 \mathrm{~h}$ at $105^{\circ} \mathrm{C}$ ).

Chemical composition of leaves

Freshly fallen leaves of the chosen plant species were collected from the forest floor. Nitrogen, soluble C, total soluble phenols, tannins, and fibers (cellulose, lignin) were analyzed at the CIRAD laboratory ("Centre de Coopération Internationale en Recherches Agronomiques pour le Développement,” Montpellier, France). The leaves were air-dried and milled, and total $\mathrm{N}$ content was measured by the Kjeldahl method. Soluble $\mathrm{C}$ compounds were extracted by mixing $2 \mathrm{~g}$ of the milled leaves in $60-\mathrm{ml}$ cold water during $2 \mathrm{~h}$ and determined by the chemical oxygen demand using the HACH method (Jirka and Carter 1975). Total soluble phenolics were extracted with $70 \%$ methanol and measured colorimetrically using the Folin-Ciocalteu method (Marigo 1973). Precipitating tannins were measured with the same method after precipitation of bovine serum albumin, washing, and re-dissolution of the precipitate (Hagerman and Butler 1978). Cellulose and lignin were analyzed by sequential digestion of fibers (Van Soest 1963). Samples (0.7 $\mathrm{g}$ of the milled leaves) were first extracted with neutral detergent. Lignocellulose ("acid detergent fiber" or ADF) was obtained after extraction with acid detergent. Lignin (“acid detergent lignin” or ADL) was obtained after hydrolysis with 72\% H2SO4. Cellulose corresponded to the difference between ADF and ADL. 


\section{Soil macroinvertebrates}

Macroinvertebrates were sampled during the wet season at both sites under the dominant tree species mentioned above, using the modified Tropical Soil Biology and Fertility method (Anderson and Ingram 1993). Ten or more trees from each species were randomly chosen in the two sites. Four samplings were achieved between 1996 and 1998. During the whole sampling period, 100 samples were taken in the natural forest and 120 in the planted forest. Under the canopy of each tree, soil macroinvertebrates were collected and sorted by hand from a soil block including litter $(30 \times 30 \times 30 \mathrm{~cm})$, which was dug out with a spade then sprinkled over a plastic sheet. Soil macroinvertebrates were determined and classified in six groups: Diplopoda, social insects (ants, termites), epigeic earthworms, anecic earthworms, insect larvae, and miscellaneous. The last group contained Coleoptera, Chilopoda, Isopoda, Dermaptera, Blattodea, Araneidae, Heteroptera, Gasteropoda, terrestrial Turbellaria, Homoptera, and Orthoptera. Macroinvertebrates were identified at species level or as morphospecies (i.e., individuals that differed from morphological features).

Soil microarthropods

In November 1996, during the wet season, microarthropods were sampled under the selected tree species in both sites, at the same time than macroinvertebrates. Twenty or more individual trees of each species were randomly chosen in the two sites. Under the canopy of each tree, one core, $100 \mathrm{~cm} 2$ in area and $9 \mathrm{~cm}$ in depth (including litter layer), was taken. These cores were divided in three layers: 0-3, 3-6, and 6-9 cm, and microarthropods were extracted within a week using the dry funnel method modified from Macfadyen (1957). During the whole sampling period, 55 samples were taken in the natural forest and 60 in the planted forest. The collected animals were classified in three groups: Collembola, Acari, and miscellaneous.

\section{Data processing}

The effect of site on soil fauna abundance and diversity was tested with analyses of variance (ANOVA). The within-site effect of plant species on soil fauna abundance and diversity was tested with nested ANOVA, using site as the main factor. The plant species effect was further explored using a posteriori multiple means 
comparisons. Fisher's least significant difference (LSD) was used for multiple means comparisons (i.e., LSD comparisons were made only when the main effect of plant species was significant at $\mathrm{p}<0.05)$. Data were $\log$ transformed to normalize the variance across treatments.

\section{Results}

Soil physicochemical characteristics

The natural forest soil had a silt loam texture and the planted forest soil had a clayish texture (Table 1). The organic matter content was significantly higher in the Leptosol (natural forest) than in the Vertisol (planted forest), Table 1. Soil moisture (bimonthly measurements) was not significantly different in the two sites (Table $1, \mathrm{p}>0.05)$

Litter analysis

Chemical analyses (Table 2) showed that freshly fallen leaves of T. heterophylla had the lowest content in lignin and tannin and were also characterized by the highest cellulose content. Freshly fallen leaves of S. macrophylla had a higher phenol content than leaves of T. heterophylla and P. subcordata. Leaves of P. subcordata had a high $\mathrm{N}$ content, more than twice that of the other species.

\section{Soil macrofauna}

A preliminary analysis of variance showed that there were no significant differences between the four sampling periods, regarding soil fauna collected under the same conditions (i.e., same plant species and site). Thus, the data collected at the four sampling dates were pooled.

Soil macrofauna abundance was significantly higher in the Vertisol of the planted forest than in the Leptosol of the natural forest (Table 3). The effect of tree species on total soil macrofauna density was highly significant $(\mathrm{p}<0.001$, Fig. 1, Table 4). B. simaruba was associated with the lowest abundance in the natural forest, and T. heterophylla was associated with the highest soil macrofauna abundance in the planted forest (Table 4). Diplopoda and epigeic earthworm abundances were the highest under T. heterophylla (Table 4). 
Tannin content in leaves of the four tree species was weakly negatively correlated with total soil macrofauna abundance $(\mathrm{p}=0.09)$.

Ninety species and morphospecies were collected over the four sampling dates (Appendix). The two sites had 40 species and morphospecies in common. Three morphospecies and species of earthworms were identified: an epigeic morphospecies Dichogater $s p$. and two anecic species Amynthas rodericensis and Polypheretima elongata. The anecic species were only found in the planted forest. Seven species of millipedes were identified. There was no significant difference between the two sites regarding soil macrofauna diversity (71 species and morphospecies in the natural forest and 61 in the planted forest). The effect of plant species on soil macrofauna community composition was highly significant $(\mathrm{F}=5.4, \mathrm{p}<0.001)$. B. simaruba in the natural forest was associated with the lowest soil macrofauna diversity. There was no significant difference between the other tree species regarding soil macrofauna diversity.

Soil microarthropods

Acari and Collembola dominated soil microarthropods in the two study sites (from 72 to $83 \%$ of total soil microarthropods). The abundance of total soil microarthropods was not significantly different between the two sites (Table 3). However the abundance of Collembola was significantly higher in the planted forest $(p<0.004$, Table 3), and the abundance of Acari was significantly higher in the natural forest ( $<<0.004$, Table 3 ). The effect of plant species on total soil microarthropod abundance was highly significant $(\mathrm{p}<0.001$, Table 4$)$. $S$. macrophylla from the planted forest and B. simaruba from the planted forest were associated, respectively, to the highest and the lowest soil microarthropod abundance (Table 4). Soil microarthropods was mainly located in the upper $3 \mathrm{~cm}$ of soils (Fig. 2). The percentage of soil microarthropods in the 3 - to 9 -cm layer of the planted forest was significantly higher than in the natural forest (p<0.001, Fig. 2).

\section{Discussion}

Soil effect

The two sites presented two distinct soil types which were primarily characterized by contrasted texture and organic matter content. Soil depth was also different within the two sites (data not shown): The Leptosol of the 
natural forest was shallow ( $\leq 55 \mathrm{~cm}$ deep), and the Vertisol of the planted forest was deeper ( $\geq 80 \mathrm{~cm}$ deep). According to the model proposed by Lavelle et al. (1993), soil biological processes are led by a succession of hierarchized factors; parameters which operate at the largest scales (climate and soil properties) constrain parameters operating at smaller scales (soil fauna and microorganisms). Under the same climatic area, the main regulation for organic matter decomposition was probably exerted by soil properties. Our data and observations corroborated this hierarchical model. In fact, under the same tree species (B. simaruba), there was a significant difference in soil fauna abundance and diversity between the two soils.

In the Vertisol under the planted forest, we found two macrofauna communities: (1) an epigeic one dominated by millipedes and (2) a soil-dwelling one dominated by the anecic earthworm P. elongata. In the Leptosol under the natural forest, we found an epigeic macrofauna community dominated by millipedes but no soil-dwelling macrofauna community. A likely explanation for this is that anecic earthworms such as P. elongata do not tolerate dehydratation. During the dry season, these worms usually move to moist, deeper soil horizons to aestivate (Lavelle and Spain 2001). Such behavior was impossible in the shallow Leptosol of the natural forest. Anecic earthworms are known to contribute to the mixing of mineral and organic material and produce solid organo-mineral aggregates that participate to the maintenance of strong macro-porosity (Alegre et al. 1996; Blanchart et al. 1997). In addition, these invertebrates homogenize the upper part of the soil profile and accelerate litter incorporation into the soil, decomposition of fresh soil organic matter, and nutrient turnover (Jabiol et al. 1995). In previous studies comparing organic matter decomposition and humus formation in the two study sites, the high impact of P. elongata on soil functioning was demonstrated. In fact, the activity of this keystone species leads to the formation of a Eumull humus form in the planted forest, which is characterized by the rapid incorporation of litter to an organo-mineral horizon with crumb aggregates (Loranger 2001; Loranger et al. 2003). The biological activity of $P$. elongata is also responsible for the much quicker litter disappearance in the planted forest as compared to the natural forest (Loranger et al. 2002).

Soil microarthropods also varied between the two sites. In the natural forest, soil microarthropod community was dominated by Acari. At this site, the high organic matter content of top layers may be favorable to these mainly fungivorous animals. In the planted forest, the microarthropod community was dominated by Collembola; these mainly saprophagous animals may feed on anecic earthworm casts and mucus (Salmon and Ponge 2001). In the natural forest, soil microarthropod activity was located at the soil surface (upper $3 \mathrm{~cm}$ ), whereas it extended to the upper $10 \mathrm{~cm}$ in the soil of the planted forest. The vertical distribution of microarthropod populations is influenced by several factors. Among them, $\mathrm{pH}$, food resources, and pore size 
have been highlighted (Ponge 1999). In our study, differences in microarthropod vertical distribution may be attributed to soil structure, in particular pore size (Didden 1987), and to vertical distribution of organic matter (Poursin and Ponge 1984), due to anecic earthworm activities.

Vegetation quality effect

Because plant species differ both in litter production and quality, individual plant species may have important effects on soil fauna and on the processes they regulate (Wardle et al. 2004). Several other studies report the effect of the chemical composition of decomposing plant material on soil fauna. Soil fauna particularly avoid litter rich in tannin-proteins complexes, polyphenols, and lignin (Satchell 1967; Satchell and Lowe 1967; Tian et al. 1993; Harbone 1997). Those tannin-proteins complexes are degradable only by white rot fungi, and microorganisms found in the guts of earthworm and isopod (Neuhauser et al. 1978). High contents in N and soluble carbohydrates are attractive for soil fauna (Bocock et al. 1960; Satchell and Lowe 1967; Tian et al. 1993).

Therefore, the higher quality of $T$. heterophylla leaves, i.e., their low tannin content ( $0.3 \%$ dry matter), probably explain the development of an abundant macrofauna community under the canopy of this species. On the contrary, soil macrofauna development was limited under B. simaruba, P. subcordata, and S. macrophylla which all have tannin-rich leaves.

\section{Conclusion}

Our study shows that, 50 years after tree plantation, soil macrofauna diversity in the planted forest was similar to that of the natural forest. Moreover, soil macrofauna abundance was higher in the planted forest. This is probably due to the fact that these sites were located on two distinct soil types, which were characterized by contrasted features. Moreover, in the planted forest, the activity of the anecic earthworm P. elongata may generate food resources (casts, mucus) and microhabitats (burrows, macroaggregates), which favor the development of other soil fauna species. Soil macrofauna abundance and diversity also depended on the tree species effect. The effect of plant litter quality varied according to each dominant tree species and was superimposed to soil effect. 
Besides, it has been shown that tree plantations may facilitate secondary succession by reestablishing nutrient cycling, providing habitat for seed dispersers, and improving the microclimate for native species establishment in the understorey (Brown and Lugo 1990). Höfer et al. (2001) also showed that in Amazonian ecosystems, soil fauna in forest plantations was similar to the fauna of the nearby primary forest and, despite structural differences (i.e., in species and dominance spectrum), reached comparable level of functional efficiency (i.e., concerning litter decomposition). Old plantations are known for their high understorey plant species richness, including many native tree species (Lugo 1992). This high plant diversity may, in turn, enhance soil animal diversity.

Acknowledgments Thanks are due to Professor Jean-Paul Mauriès (Muséum National d'Histoire Naturelle, Paris) for identifying the millipedes at the species level. We thank Serge, Rose, Kenny and Karen Loranger, Patrick Merciris, Alain Dufrénot, Maguy Dulormne, Vanessa Hequet, Rachel Morton, and Emile Timodent for their valuable help in the field and in the laboratory. We thank the "Office National des Forêts" (ONF) for free access to the plantation forest (Pouzzole domain). Thanks are also due to Dr. Jean-Pierre Rossi (INRA Bordeaux-Aquitaine) and Dr. Sébastien Barot (IRD Bondy) for their advices on statistical analyses.

\section{Appendix}

Soil macrofauna species and morphospecies collected in a natural forest and in a planted forest in North GrandeTerre (Guadeloupe)

1. Diplopoda: 7 species (Orthomorpha coarctata Saussure; Anadenobolus monilicornis von Porat; Trigoniulus corallinus Gervais; Spirostrophus naresi Pocock; Epinannolene pittieri guadeloupensis Mauriès; Pseudospirobolellus avernus Butler; Siphonophora filiformis Mauriès)

2. Chilopoda: 3 morphospecies

3. Coleoptera: 4 species (Phyllophaga patrueloides Paulian, Phyllophaga pleei Blanchard, Anomala insularis Castelnau, Aspisoma ignita Linnaeus) and 13 morphospecies

4. Formicidae: 4 species (Acromyrmex octospinosus Reich, Ectatomma ruidum Roger, Odontomachus chelifer Latreille, Azteca delpini antillana Forel) and 9 morphospecies 
5. Isoptera: 1 species (Nasutitermes costalis Holmgren) and 2 morphospecies

6. Earthworms: 2 species (P. elongata Perrier; A. rodericensis Grube) and 1 morphospecies (Dichogaster sp.)

7. Insect larvae: 17 morphospecies

8. Isopoda: 3 morphospecies

9. Dermaptera: 1 morphospecies

10. Blattodea: 1 species (Hemiblabera granulata Saussure and Zehntner) and 2 morphospecies

11. Araneidae: 13 morphospecies

12. Heteroptera: 2 morphospecies

13. Gasteropoda: 1 morphospecies

14. Turbellaria: 1 morphospecies

15. Homoptera: 1 morphospecies

16. Orthoptera: 2 morphospecies

\section{References}

Alegre JC, Pashanasi B, Lavelle P (1996) Dynamics of soil physical properties in a low input agricultural system inoculated with the earthworm Pontoscolex corethrurus in the Amazon region of Peru. Soil Sci Soc Am J 60:1522-1529

Anderson JM, Ingram JSI (1993) Tropical soil biology and fertility: a handbook of methods, 2nd edn. CAB International, Oxon

Bernhard-Reversat F, Laclau JP, Loubana PM, Loumeto JJ, Mboukou IMC, Reversat G (2001) Changes in biological factors of fertility in managed eucalyptus plantations on a savanna soil in Congo. In: 
Kobayashi S et al (eds) Rehabilitation of degraded tropical forest ecosystems: workshop proceedings. CIFOR, Bogor, pp 179-190

Blanchart E, Lavelle P, Braudeau E, Le Bissonais Y, Valentin V (1997) Regulation of soil structure by geophagous earthworm activities in humid savannas of Côte d'Ivoire. Soil Biol Biochem 29:431-439

Bocock KL, Gilbert O, Capstick CK, Twinn DC, Waid JS, Woodman MJ (1960) Changes in leaf litter when placed on the surface of soils with contrasting humus types. I. Losses in dry weight of oak and ash leaf litter. J Soil Sci 11:1-9

Brown S, LugoAE (1990) Tropical secondary forests. J Trop Ecol 6:1-32

Didden WAM (1987) Reactions of Onychiurus fimatus (Collembola) to loose and compact soil. Methods and first results. Pedobiologia 30:93-100

Driessen P, Deckers J, Spaargaren O, Nachtergaele F (2001) Lecture notes on the major soils of the world. FAO, Rome

Gillespie TW (1999) Life history characteristics and rarity of woody plants in tropical dry forest fragments of Central America. J Trop Ecol 15:637-649

Hagerman AE, Butler LG (1978) Protein precipitation method for the quantitative determination of tannins. J Agric Food Chem 26:809-812

Harbone JB (1997) Role of phenolic secondary metabolites in plants and their degradation in nature. In: Cadish G, Giller KE (eds) Driven by nature: plant litter quality and decomposition. CAB International, London, pp 67-74

Höfer H, Hanagarth W, Garcia M, Martius C, Franklin E, Römbke J, Beck L (2001) Structure and function of soil fauna communities in Amazonian anthropogenic and natural ecosystems. Eur J Soil Biol 37:229235

Imbert D, Portecop J (1992) La forêt tropicale semi-décidue de la Guadeloupe: structures spatiales et production de litière dans la région nord de la Grande-Terre. In: Actes Colloque de Botanique (eds) Pérennité et évolution de la flore des Caraïbes. Terre-de-Haut, Guadeloupe, March 1-4, 1990, Conservatoire des jardins et paysages, pp 52-70 
Jabiol B, Brêthes A, Ponge JF, Toutain F, Brun JJ (1995) L'humus sous toutes ses formes. Service EditionENGREF, Nancy

Janzen DH (1988) Tropical dry forests: the most endangered major tropical ecosystem. In: Wilson EO (ed) Biodiversity. National Academy, Washington, DC, pp 130-137

Jirka AM, Carter MJ (1975) Micro semi-automated analysis of surface and wastewaters for chemical oxygen demand. Anal Chem 47:1397-1402

Lavelle P (1997) Faunal activities and soil processes: adaptive strategies that determine ecosystem function. Adv Ecol Res 27:93-132

Lavelle P, Spain AV (2001) Soil ecology. Kluwer, Amsterdam

Lavelle P, Blanchart E, Martin A, Martin S, Spain A, Toutain F, Barois I, Schaefer R (1993) A hierarchical model for decomposition in terrestrial ecosystems: application to soils of the humid tropics. Biotropica $25: 130-150$

Lerdau M, Whitbeck J, Holbrook NM (1991) Tropical deciduous forest: death of a biome. Trends Ecol Evol $6: 201-202$

Loranger G (2001) Formes d'humus originales dans une forêt semidécidue de la Guadeloupe/Particular humus forms in a tropical semi-evergreen forest of Guadeloupe. C R Acad Sci Ser 3 Sci Vie 324:725-732

Loranger G, Ponge JF, Imbert D, Lavelle P (2002) Leaf decomposition in two semi-evergreen tropical forests: influence of litter quality. Biol Fertil Soils 35:247-252

Loranger G, Ponge JF, Lavelle P (2003) Humus forms in two secondary semi-evergreen tropical forest stands. Eur J Soil Sci 54:17-24

Lugo AE (1992) Comparison of tropical tree plantations with secondary forests of similar age. Ecol Monogr $62: 1-41$

Lugo AE, Schmidt R, Brown S (1981) Tropical forests in the Caribbean. Ambio 10:318-324

Macfadyen A (1957) Animal ecology. Aims and methods. Pitman, London 
Marigo G (1973) Sur une méthode de fractionnement et d'estimation des composés phénoliques chez les végétaux. Analusis 2:106-110

Murphy PG, Lugo AE (1986) Ecology of tropical dry forest. Ann Rev Ecolog Syst 17:67-88

Neuhauser EF, Hartenstein R, Connors WJ (1978) Soil invertebrates and the degradation of vanillin, cinnamic acid, and lignins. Soil Biol Biochem 10:431-435

Petersen H, Luxton M (1982) A comparative analysis of soil fauna populations and their role in decomposition processes. Oikos 93:297-388

Ponge JF (1999) Interaction between soil fauna and their environment. In: Rastin N, Bauhus J (eds) Going underground - ecological studies in forest soils. Research Signpost, Trivandrum, Kerala, pp 45-76

Poursin JM, Ponge JF (1984) Etude des peuplements de microarthropodes (Insectes Collemboles et Acariens Oribates) dans trois humus forestiers acides de la Forêt d'Orléans (Loiret, France). Pedobiologia 26:403-414

Salmon S, Ponge JF (2001) Earthworm excreta attract soil springtails: laboratory experiments on Heteromurus nitidus (Collembola: Entomobryidae). Soil Biol Biochem 33:1959-1969

Satchell JE (1967) Lumbricidae. In: Burges A, Raw F (eds) Soil biology. Academic, New York, pp 259-322

Satchell JE, Lowe DG (1967) Selection of leaf litter by Lumbricus terrestris. In: Graff O, Satchell JE (eds) Progress in soil biology. North Holland Company, Amsterdam, pp 102-119

Tian G, Brussaard L, Kang BT (1993) Biological effects of plant residues with contrasting chemical compositions under humid tropical conditions: effects on soil fauna. Soil Biol Biochem 25:731-737

Van Soest PJ (1963) Use of detergents in the analysis of fibrous feeds. II. A rapid method for determination of fiber and lignin. J Assoc Off Agric Chem 46:829-835

Wardle DA, Bardgett RD, Klironomos JN, Setälä H, Van der Putten WH, Wall DH (2004) Ecological linkages between aboveground and belowground biota. Science 304:1629-1633

Warren W, Zou X (2002) Soil macrofauna and litter nutrients in three tropical tree plantations on a disturbed site in Puerto Rico. For Ecol Manag 170:161-171 


\section{Legends of figures}

Fig. 1 Soil macrofauna abundance (indivuals $\mathrm{m}^{-2}$ ) under five selected plant species in a natural forest and in a planted forest in North Grande-Terre (Guadeloupe)

Fig. 2 Abundance and distribution of soil microarthropods between 0- and 9-cm depth, under five selected plant species in a natural forest and a planted forest in North Grande-Terre (Guadeloupe) 
Table 1 Soil physicochemical characteristics of a Leptosol (natural forest) and a Vertisol (planted forest) inNorth Grande-Terre (Guadeloupe)

\begin{tabular}{|c|c|c|c|}
\hline & $\begin{array}{l}\text { Natural } \\
\text { forest }\end{array}$ & $\begin{array}{l}\text { Planted } \\
\text { forest }\end{array}$ & $p$ \\
\hline \multicolumn{4}{|c|}{ A horizon (upper horizon) } \\
\hline$\%$ Clay & $10(1)$ & $78(0.1)$ & $<0.001$ \\
\hline$\%$ Silt & $71(3)$ & $14(0.1)$ & $<0.001$ \\
\hline$\%$ Sand & $19(4)$ & $8(0.2)$ & ns \\
\hline \multicolumn{4}{|c|}{ A/C or SV horizon (deeper horizon) } \\
\hline$\%$ Clay & $49(3)^{\mathrm{a}}$ & $76(1.3)^{b}$ & $<0.001$ \\
\hline$\%$ Silt & $28(3)^{\mathrm{a}}$ & $14(0.1)^{\mathrm{b}}$ & $<0.001$ \\
\hline$\%$ Sand & $23(5)^{\mathrm{a}}$ & $10(0.8)^{b}$ & ns \\
\hline $\mathrm{C}_{0-10 \mathrm{~cm}}(\%)$ & $22(5)$ & $6(0.5)$ & $<0.001$ \\
\hline $\mathrm{C}_{10-20 \mathrm{~cm}}(\%)$ & $13(5)$ & $5(0.6)$ & $<0.001$ \\
\hline $\mathrm{C}_{20-30 \mathrm{~cm}}(\%)$ & $11(2)$ & $2(0.2)$ & $<0.001$ \\
\hline $\mathrm{C}_{30-40 \mathrm{~cm}}(\%)$ & $9(2)$ & $1.5(0.1)$ & $<0.001$ \\
\hline $\mathrm{N}_{0-10 \mathrm{~cm}}(\%)$ & $2(0.3)$ & $0.5(0.04)$ & $<0.001$ \\
\hline $\mathrm{N}_{10-20 \mathrm{~cm}}(\%)$ & $1.2(0.2)$ & $0.4(0.02)$ & $<0.001$ \\
\hline $\mathrm{N}_{20-30 \mathrm{~cm}}(\%)$ & $0.9(0.2)$ & $0.2(0.02)$ & $<0.001$ \\
\hline $\mathrm{N}_{30-40 \mathrm{~cm}}(\%)$ & $0.8(0.2)$ & $0.1(0.01)$ & $<0.001$ \\
\hline Soil moisture (\%) & $31(8)$ & $33(5)$ & ns \\
\hline
\end{tabular}

Standard errors are given in parentheses. $d f=1$ ns Non significant

${ }^{\mathrm{a}} \mathrm{A} / \mathrm{C}$ horizon

${ }^{\mathrm{b}} \mathrm{SV}$ horizon 
Table 2 Chemical composition of freshly fallen leaves of five selected tree species, in a natural forest and in a planted forest in North Grande-Terre (Guadeloupe)

\begin{tabular}{|c|c|c|c|c|c|c|}
\hline & Natural fore & & Planted fore & & & $\mathrm{p}$ \\
\hline & B & $\mathrm{P}$ & B & $\mathrm{S}$ & $\mathrm{T}$ & \\
\hline Total N (\%) & $1.1(0.1)^{b}$ & $2.5(0.1)^{\mathrm{a}}$ & $1.01(0.1)^{b}$ & $1.1(0.1)^{b}$ & $0.9(0.1)^{b}$ & $<0.001$ \\
\hline Soluble C (\%) & $8.3(0.3)$ & $2.4(0.5)$ & $8.3(0.3)$ & $3.0(0.3)$ & $5.3(0.3)$ & ns \\
\hline Soluble phenols (\%) & $10.0(1.0)^{\mathrm{ab}}$ & $6.7(0.6)^{\mathrm{bc}}$ & $10.0(1.0)^{\mathrm{ab}}$ & $12.7(0.6)^{\mathrm{a}}$ & $4.5(2.3)^{\mathrm{c}}$ & 0.01 \\
\hline Tannins (\%) & $3.3(0.7)^{\mathrm{a}}$ & $1.8(0.8)^{\mathrm{a}}$ & $3.3(0.7)^{\mathrm{a}}$ & $2.9(0.6)^{\mathrm{a}}$ & $0.3(0.1)^{b}$ & 0.03 \\
\hline Cellulose $(\%)$ & $20.9(0.4)^{b}$ & $19.2(0.6)^{b}$ & $20.9(0.4)^{b}$ & $19.8(4.1)^{b}$ & $32.1(2.3)^{\mathrm{a}}$ & 0.01 \\
\hline Lignin (\%) & $22.8(9.6)^{\mathrm{a}}$ & $29.5(15.1)^{\mathrm{a}}$ & $22.8(9.6)^{\mathrm{a}}$ & $29.1(10.0)^{\mathrm{a}}$ & $12.0(2.1)^{b}$ & 0.05 \\
\hline
\end{tabular}

Values (percent of dry matter) are means of three replicates; standard errors are given in parentheses. For each tree species, means with the same letter are not significantly different based on a LSD test. $\mathrm{df}=3$

ns Nonsignificant; B Bursera simaruba; P Pisonia subcordata; S Swietenia macrophylla; T Tabebuia heterophylla 
Table 3 Means (individuals per m2), standard errors (in parentheses), F ratio, and p values (ANOVA tests) for the responses of soil fauna abundance to site effects in a natural forest and in a planted forest in North GrandeTerre (Guadeloupe)

\begin{tabular}{|c|c|c|c|c|}
\hline & $\begin{array}{l}\text { Natural } \\
\text { forest }\end{array}$ & $\begin{array}{l}\text { Planted } \\
\text { forest }\end{array}$ & $F$ & $p$ \\
\hline Diplopoda & $37(7)$ & $82(14)$ & 32.7 & $<0.001$ \\
\hline Epigeic earthworms & $2(1)$ & $10(3)$ & 8.4 & 0.004 \\
\hline Anecic earthworms & $0(0)$ & $7(2)$ & 9.8 & 0.002 \\
\hline Insect larvae & $9(2)$ & $33(9)$ & 27.6 & $<0.001$ \\
\hline Social insects & $20(6)$ & $31(11)$ & 0.1 & ns \\
\hline Total soil macrofauna & $100(14)$ & $183(24)$ & 32.8 & $<0.001$ \\
\hline Collembola & $1.104(3.103)$ & $2.104(3.103)$ & 8.5 & 0.004 \\
\hline Acari & $3.104(4.103)$ & $2.104(2.103)$ & 8.8 & 0.004 \\
\hline Total soil microarthropods & $5.104(7.103)$ & $6.104(6.103)$ & 0.4 & $\mathrm{~ns}$ \\
\hline
\end{tabular}


Table 4 Means (individuals per $\mathrm{m}^{2}$ ), standard errors (in parentheses), F ratio, and $\mathrm{p}$ values (ANOVA tests) for the responses of soil fauna abundance to plant species nested within sites effect [plant species (sites)], in a natural forest and in a planted forest in North Grande-Terre (Guadeloupe)

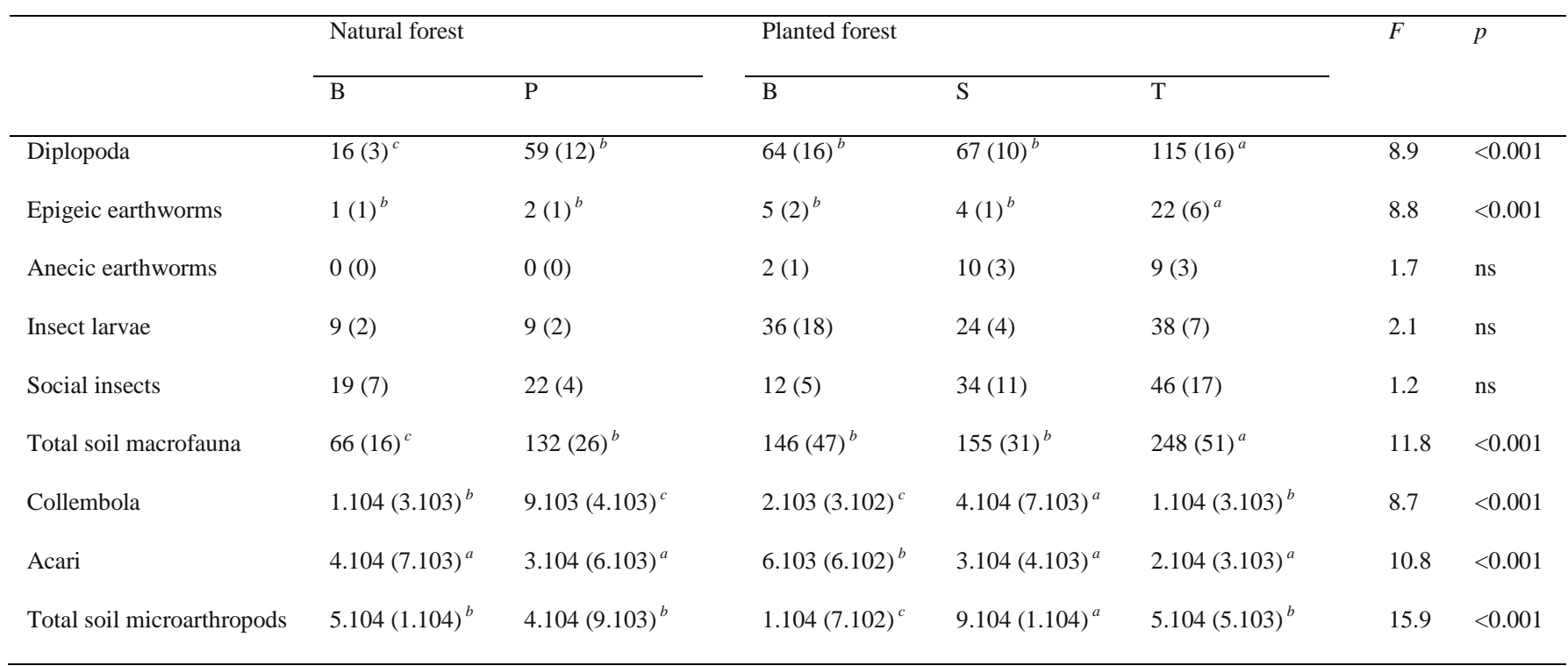

For each group, means with the same letter are not significantly different based on LSD. $d f=3$

ns Nonsignificant; B Bursera simaruba; P Pisonia subcordata; S Swietenia macrophylla; T Tabebuia heterophylla 


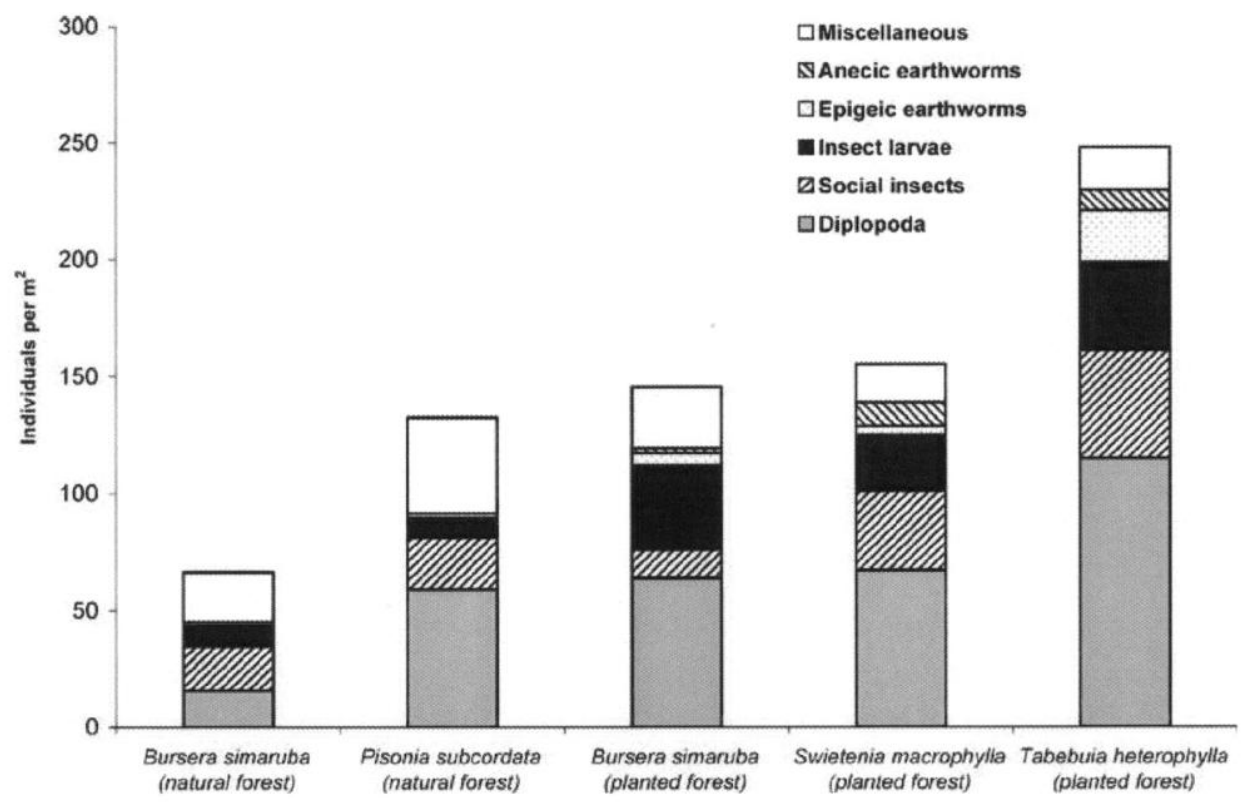

Fig. 1 


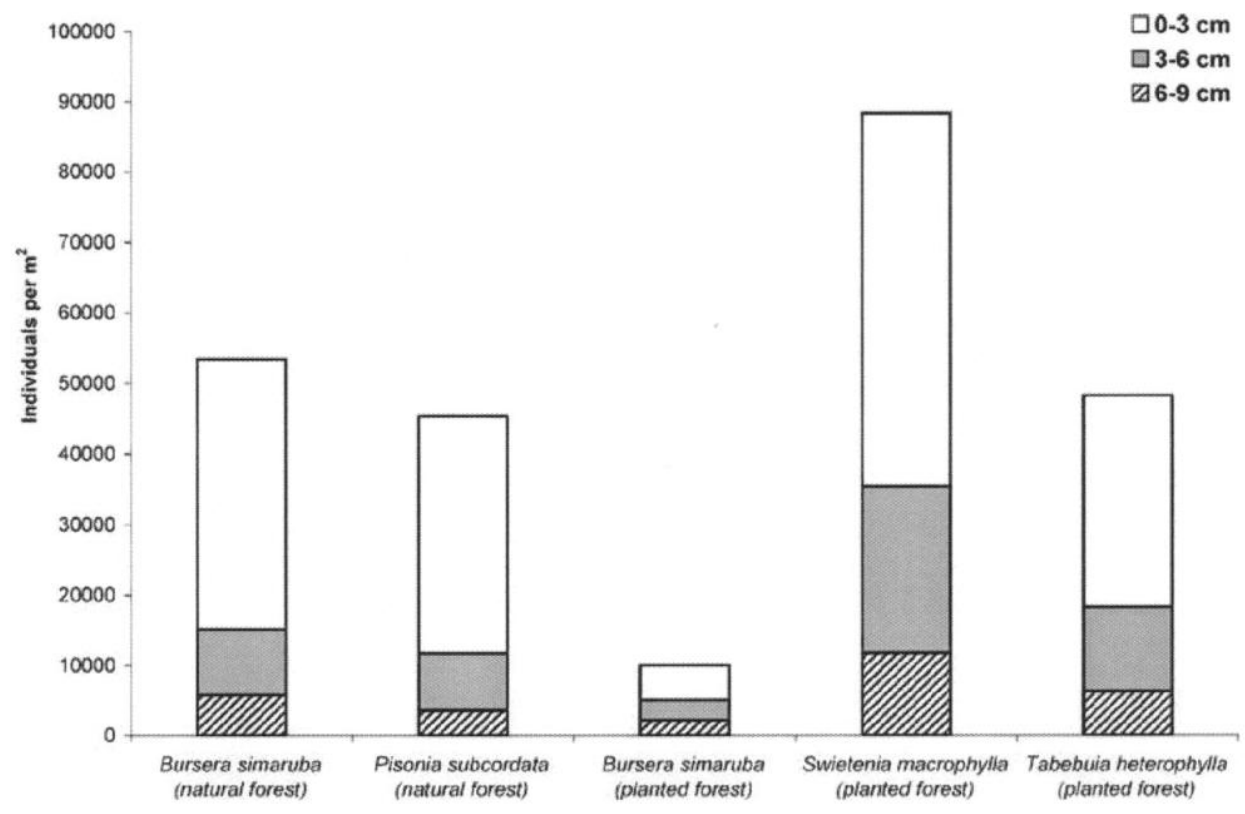

Fig. 2 